\title{
Michael W. Champion, Kirk Essary and Juanita Feros Ruys (eds.), Before Emotion: The Language of Feeling, 400-1800, New York/London, Routledge, 2019, 262 pp. ISBN: 9780367086022. Cloth: $£ 120$
}

Reseñado por JACK FORD University College London (UCL), UK

jack.ford.13@ucl.ac.uk

What was the significance of pre- and early modern theories of affect, feelings, and affectio? Specifically, how did the premodern cognates of 'affect' and 'affection' - affectus, affection, and affeccioun - contribute to shaping discourses surrounding these keywords? The three editors and 20 distinguished authors that have come together to write Before Emotion: The Language of Feeling, 400-1800, a new collection of essays published as the fourteenth entry under the Routledge 'Series in Medieval Literature and Culture', have taken bold strides forward to answering these difficult questions - questions that until now have received no systematic analysis.

The architects behind this ambitious project, editors Juanita Feros Ruys (University of Sydney), Michael W. Champion (Australian Catholic University) and Kirk Essary (University of Western Australia), were ideally suited to this task on account of the pedigree of their previous research, ${ }^{1}$ which is both chronologically and thematically wide-reaching, and has contributed greatly to the still burgeoning field of the history of emotions. All are members of the interdisciplinary research currently being sponsored by the Australian Research Council's (ARC) Centre of Excellence for the Emotions (CHE), the latest

\footnotetext{
${ }^{1}$ The most relevant publications are Champion, M., Garrod, R., Haskell, Y., and Ruys, J.F., «But Were They Talking About Emotions? Affectus, affectio and the History of Emotions», Revista Storica Italiana, 128/2 (2016), pp. 521-543; Champion, M. and M. Stanyon, «'A Possession for Eternity': Thomas de Quincey's Feeling for War», in S. Downes, K. O'Loughlin and A. Lynch (eds.), Writing War in Britain and France, 1370-1854: A History of Emotions, London/New York, Routledge, 2019; Champion, M., and Lynch, A. (eds.), Understanding Emotions in Early Europe, Turnhout, Brepols, 2015); Essary, K. and Haskell, Y., «Calm and Violent Passions: The Genealogy of Distinction from Quintilian to Hume», Erudition and the Republic of Letters, 3/1 (2018), pp. 55-81; Essary, K., «Enduring Erasmus: Reception and Emotion in Christian Humanism», Church History and Religious Culture, 97 (2017), pp. 322-333; Essary, K., «Annotating the Affections: The Philology of Feeling in Erasmus' New Testament Scholarship and its Reception in Early Modern Dictionaries'», Erasmus Studies, 37/2 (2017), pp. 193-216; Essary, K., «Passions, Emotions, or Affections? On the Ambiguity of 16th-Century Terminology», Emotion Review, 9/4 (2017), pp. 367-74; Ruys, J. and Monagle, C. (eds.), A Cultural History of the Emotions in the Medieval Age, London, Bloomsbury, 2019; Ruys, J., «From Virtue Ethics to Emotional Intelligence: Advice from Medieval Parents to their Children», in K. Moruzi, M. J. Smith and E. Bullen (eds.), Affect, Emotion and Children's Literature: Representation and Socialisation in Texts for Children and Young Adults, London, Routledge, 2018; Ruys, J. and McNamara, R.F., «Unlocking the Silences of the Self-Murdered: Textual Approaches to Suicidal Emotions in the Middle Ages», Exemplaria, 26/1 (2014), pp. 58-80.
} 
in a line of research institutes ${ }^{2}$ set up to coordinate projects aimed at furthering the understanding of premodern accounts of emotion. ${ }^{3}$

This volume has been built upon the uncompromising contention that affectus and its cognates have hitherto been overlooked within scholarship; 'affect' as a concept is located at the crossroads of life for medieval and early-modern contemporaries and, therefore, deserving of much-needed rehabilitation. As Champion, Essary and Ruys note in their introduction: «understanding affectus draws historians into narratives of anthropology, ethics, theology, cosmology, and eschatology, and its associated social, rhetorical, medical, political, and religious practices» (p. 6). I must agree. Upon reading this collection, I was repeatedly struck by the porous nature of the term affectus and its significance in offering a framework for inspecting the structures of premodern experience. The bold mission statement of Before Emotion, and its ability to deliver on it, thus confers this new book a vital role within the historiography of the emotions.

It is no secret that the so-called 'affective turn' within the historical and social sciences has benefitted from the pioneering studies of Peter and Carol Stearns, Barbara H. Rosenwein, and William M. Reddy. These studies have yielded several, now widely used, conceptual frameworks for analysing emotion, including 'emotionology', 'emotives', 'structures of feeling', and 'the emotional community'. ${ }^{4}$ Before Emotion succeeds in building upon these now classic studies (with resonances of emotives and emotional communities especially to be found in the background in many of the essays in this volume). This

\footnotetext{
${ }^{2}$ Other institutes include: The Institute for the Study of Emotions, Florida State University; Les Émotions au Moyen Âge (EMMA), Universities of Aix-Marseille and Québec à Montréal; International Network for the Cultural History of Emotions in Premodernity (CHEP), University of Umeå; Languages of Emotion, Freie Universität Berlin; Centre for the History of Emotions, Max Planck Institute for Human Development; Queen Mary Centre for the History of Emotions, University of London; and Emotional Culture and Identity (CEMID), Institute of Culture and Society at University of Navarra. ${ }^{3}$ Major publications from CHE include the Cultural History of the Emotions series edited by Susan Broomhall, Jane W. Davidson and Andrew Lynch, in addition to the biannual journal, Emotions, History, Culture, Society, published by Brill and edited by Katie Barclay, Andrew Lynch and Giovanni Tarantino.

${ }^{4}$ Rosenwein, B.H. (ed.), Anger's Past: The Social Uses of an Emotion in the Middle Ages, Ithaca and London, Cornell University Press, 1998; Rosenwein, «Worrying about Emotions in History», The American Historical Review, 107/3 (2002), pp. 821-845; Rosenwein, «Problems and Methods in the History of Emotions», Passions in Context, 1 (2010), pp. 1-32; Rosenwein, Generations of Feeling: A History of Emotions, 600-1700, Cambridge, Cambridge University Press, 2016); Reddy, W.M., «Against Constructionism: The Historical Ethnography of Emotions», Current Anthropology, 38/3 (1997), pp. 327-351; Reddy, The Navigation of Feeling: A Framework for the History of Emotions, Cambridge, Cambridge University Press, 2001; Stearns P.N. and Stearns, C.Z., «Emotionology: Clarifying the History of Emotions and Emotional Standards», American Historical Review, 90 (1985), pp. 813-836; Plamper, J., «The History of Emotions: An Interview with William Reddy, Barbara Rosenwein, and Peter Stearns» History and Theory, 49/2 (2010), pp. 237-265.
} 
offering by Champion, Essary and Ruys also adds to the voluminous philosophical ${ }^{5}$ and historiographical accounts of emotion ${ }^{6}$, in addition to contributing to scholarship of the more specific area of the affections in the fields of literature ${ }^{7}$, art history ${ }^{8}$, gender studies ${ }^{9}$, and the recent longue durée syntheses under the direction of Dale M. Coulter and Amos Yong ${ }^{10}$ at Regents University and those of Damien Boquet and Piroska Nagy. ${ }^{11}$

A secondary aim of Before Emotion is to offer a constructive critique of the praxis of modern affect theory which, drawing upon theoretical models of Giles Deleuze and Felix Guatarri, Brian Massumi, Eric Shouse, Antonio Damasio, and William James and Carl Lange (James-Lange theory), subscribes to a reductive view of emotion as materialistic and preconscious. ${ }^{12}$ The primary purpose of this new collection, however, is situated squarely within the lexical history of emotion. If Boquet and Nagy's 2018 Medieval Sensibilities proposed a 'cultural history of affectivity' ${ }^{13}$, Champion, Essary and Ruys' Before Emotion provides its counterpart: a linguistic history of affectivity. This collection thus adds to earlier attempts to achieve greater clarity on the precise meanings of technical Latin

\footnotetext{
${ }^{5}$ Sorabji, R., Emotion and Peace of Mind: From Stoic Agitation to Christian Temptation, Oxford, Oxford University Press, 2000; Nussbaum, M., Upheavals of Thought: The Intelligence of the Emotions, Cambridge, Cambridge University Press, 2001; Knuuttila, S., Emotions in Ancient and Medieval Philosophy, Oxford, Oxford University Press, 2004; Dror, O.E., Hitzer, B., Laukötter A., and León-Sanz, P., «An Introduction to History of Science and the Emotions», Osiris, 31 (2016), pp. 1-18; Boquet and Nagy, «Medieval Sciences of the Emotions during the Eleventh to Thirteenth Centuries: An Intellectual History», Osiris, 31 (2016), pp. 21-45.

${ }^{6}$ Dixon, T., From Passions to Emotions: The Creation of a Secular Psychological Category, Cambridge, Cambridge University Press, 2003; Plamper, J., The History of Emotions: An Introduction (trans.) K. Tribe, Oxford, Oxford University Press, 2015; Boddice, R., «The History of Emotions: Past, Present, Future», Revista de Estudios Sociales, 62 (2017), pp. 10-15; Boddice, The History of Emotions, Manchester, Manchester University Press, 2018; Crocker, H.A., «Medieval Affects Now», Exemplaria, 29/1 (2017), pp. 82-98.

7 Burger, G. D. and Crocker, H.A. (eds.), Medieval Affect: Feeling, and Emotion, Cambridge, Cambridge University Press, 2019.

${ }^{8}$ Binski, P., Gothic Sculpture, New Haven, Yale University Press, 2019.

${ }^{9}$ McNamer, S., Affective Meditation and the Invention of Medieval Compassion, University of Pennsylvania Press, 2010; Monagle, C., Scholastic Affect: Gender, Maternity and the History of Emotions, Cambridge, Cambridge University Press, 2020.

${ }^{10}$ Coulter, D.M. and Young, A. (eds.), The Spirit, the Affections, and the Christian Tradition, Notre Dame, Notre Dame Press, 2016.

${ }^{11}$ Boquet, D. and Nagy, P., Medieval Sensibilities: A History of Emotions in the Middle Ages, Cambridge, Polity Press, 2018; Boquet, D. and Nagy, P. (eds.), Le sujet des émotions au Moyen Âge, Paris, Beauchesne, 2008); Boquet, D., L'ordre de l'affect au Moyen Âge. Autour de l'anthropologie affective d'Aelred de Rievaulx, Caen, Crahm, 2005.

${ }^{12}$ Deleuze, G. and Guattari, F., A Thousand Plateaus, trans. B. Massumi, Minneapolis, University of Minnesota Press, 1987; Massumi, B., Parables for the Virtual: Movement, Affect, Sensation, Durham/London, Duke University Press, 2002); Shouse, E., «Feeling, Emotion, Affect», M/C Journal, 8/6 (2005); James, W., The Principles of Psychology, New York, Henry Holt and Company, 1890; Damasio, A.R., Looking for Spinoza: Joy, Sorrow, and the Feeling Brain, London, William Heinemann, 2003.

${ }^{13}$ Boquet and Nagy, Medieval Sensibilities, op. cit., p. 7.
} 
and vernacular emotion words. ${ }^{14}$ The delightfully autobiographical preface by Thomas Dixon reminds the reader that there is no single translation of affectus and that affective experiences as documented by historical texts are, by nature, encountered by the historian through the mediating prism of language (xii-xv). 'Each author was given a brief to zero in on the keyword [affectus], including its associations, argument contexts, and ways in functioned within particular genres, theories, practices, and forms of life', the editors remark (p. 3). The first major purpose of Before Emotion, then, is that it seeks to put the history of the term affectus on the map.

In doing so, the authors of Before Emotion naturally draw upon the methods of the 'linguistic turn' by treating emotion as a discursive phenomenon. To my mind, such a decision offers three main advantages.

First, it enhances the methodological strength of this book: by eschewing broad stroke generalisations and instead zeroing in on the specific contexts and - often contradictory - significations of affectus as if with a fine-toothed comb, the contributors sidestep issues of teleology or oversimplification.

Second, the extensive chronological scope of this research, beginning with the Stoic translation of affectus from the Greek pathe and culminating with David Hume in the eighteenth century, showcases a series of interconnected vignettes which display how affect was significant in shaping synchronic theological, ethical, cultural, political and gender practices and its importance as a 'travelling' diachronic concept. Placing the development of this term upon a continuum enables readers to notice how the concept morphs over time. A further strength of this methodology of close reading is that it enables the contributors to scrutinise existing truisms within the emotional studies. For example, the critical readings of the scholarship of Thomas Aquinas in giving prominence to the passiones ('passions') as opposed to the affectiones ('affections'), as discussed in the essays of Tomas Zahora and Waldow, I believe, is an example of the history of emotions at its finest. A consequence of this longue durée approach is that every article in this collection highlights areas where further research is needed. Lexically, affectus is shown to be part of an ever-expanding constellation of affective terminology - a semantic field that includes both Latin and vernacular terms such as animus, anima, mens, cor, passio, habitus, passiones, intellectus, constantiae, effectus, defectus, voluntas, appetitus, accidentia anime, humours, motions and sentiment, among others - which requires further study. The need to «conduct synchronic research on what happened to the nouns affectus and affectio when they were translated into vernacular languages» (p. 170) is stressed. Overall, whole entire avenues

${ }^{14}$ This is largely due to the research of Barbara H. Rosenwein, such as the lists of emotions in Generations and Feeling (2016) [note 4], or her essay «Emotion Words», in Boquet and Nagy, Le sujet des émotions au Moyen Âge, op. cit. Other notable studies include: Dixon, T., «'Emotion’: The History of a Keyword in Crisis», Emotion Review, 4/4 (2012), pp. 338-344; Champion et al., «But Were They Talking About Emotions?», op. cit.; and Essary, «Passions, Emotions, or Affections?», op. cit. 
of scholarship, such as the categories of gender, age and social class, are tantalisingly teased out.

Third, the studies in this volume reveal that affectus permeated nearly every genre of writing across the classical, medieval and early-modern periods. Philosophical treatises, grammatical and rhetorical textbooks, letter collections, spiritual and mystical handbooks, theology, medicine, treatises on the passions, works on the soul, English devotional works, translations of scripture, dictionaries, and poetry, are all treated here. The diffusion of affective terminology, theory and practices throughout such diverse corpora of texts highlights the conceptual richness and widespread significance of the Latin term affectus within the textual tradition of western Europe.

While it would be impossible to do justice to the all the brilliant insights raised within the 19 essays of this collection, I would be remiss in failing to summarise their principal contributions. Jonathan D. Teubner's «The Failure of Affectus: Affectiones and constantiae in Augustine of Hippo» (pp. 9-25) opens the collection with an investigation into one of the most important thinkers on affectus: Saint Augustine. In this essay, Augustine's psychology of affections is contextualised within his influential political theory of the communal project to transform sinful Christendom (the Earthly City) into a civilisation of virtue (the City of God). Treading a middle ground between the thought of previous interpreters of the bishop of Hippo's theology, ${ }_{15}^{15}$ Teubner stresses the role of Augustine's thought on the practices of prayer and the activity of the Holy Spirit in transforming instable, temporal human affectiones ('affections') into their blessed, stable equivalents, called constantiae. Thus, Teubner's study sets the tone of Before Emotion by revealing how, within Augustine's holistic approach to the affections, the temporal dimensions of present and future, as well as the fields of psychology, politics, pneumatology and eschatology, are unified.

This is followed by Mark Amsler's article «Affectus in Medieval Grammar» (pp. 26-37), a granular study of the use of affectus within grammatical treatises. This noun, Amsler usefully shows, was employed as an interjection in the 'intentionalist' grammar from Donatus (4th c) to emphasises strong emotions. Such a use had its heyday in the thirteenth century before fading out of use after 1350 as a theoretical concept in grammar (p. 33). Rita Copeland offers a complementary study with her analysis in chapter three of the genre of rhetorical texts, «Affectio-affectus in Latin Rhetoric up to c.1200» (pp. 38-50). And Antonina Harbus' «The Old English Vocabulary of Emotions: Glossing Affectus» (pp. 51-60) rounds off a triplet of essays seeking to understand how the term affectus was interpreted by translators and glossators. Old English terms for affectus are often passed over in the existing literature, yet as Harbus shows, more attention should be paid to this vernacular

${ }^{15}$ Byers, S.C., Perception, Sensibility, and Moral Motivation in Augustine: A Stoic-Platonic Synthesis, Cambridge, Cambridge University Press, 2010; Wetzel, J., «Prodigal Heart: Augustine's Theology of the Emotions», in J. Wetzel (ed.), Parting Knowledge: Essays after Augustine, Eugene, OR, Cascade Books, 2013. 
as the difficulty with which translators had in translating this term reveals the versatility and polyvalent nature of the Latin connotations of affectus.

The fifth contribution by editor Juanita Feros Ruys, «Before the Affective Turn: Affectus in Heloise, Abelard and the Woman Writer of the Epistolae durorum amantium» (pp. 6175), begins a series of essays discussing the prominence of the term affectus among the affective monastic communities of the twelfth and thirteenth centuries such as the Cistercians, Victorines, Franciscans and the Benedictine nuns at Rupertsberg and Helfta. Ruys, who has expended significant energy in the past to understanding the thought of Abelard ${ }^{16}$ carefully lays out how Abelard's and Heloise's theory of the affections owed less to the developments originating within the cloisters but rather to the Augustinian tradition of affectus as relayed by Teubner (p. 61). Within this context, Ruys' finding that the 'sense we get, then, is of Heloise and Abelard as the last major twelfth-century philosophers writing and thinking about affectus at the moment of the 'affective turn'... while remaining remote from the valence of this term in the practice of affective devotion' (ibid) is an important one for historians of affectivity as it highlights the plasticity of affective terminology and the accommodating milieu of early scholasticism and twelfthcentury monasticism.

The following essay, Michael D. Barbezat's «The Use of the Latin affectus in Hugh of Saint Victor's De archa Noe» (76-85) explains with admirable clarity the Augustinian roots of magister Hugh's decision to render affectus along Augustinian lines as 'the desire of enjoying something thoroughly', and how for the Victorines, affectus was 'the lynchpin in humanity's disorder' (pp. 77-78), revealing the centrality of the term to this reforming institution. While De archa Noe ('On Noah's Ark') has been widely studied before, ${ }^{17}$ and to a lesser extent, accounts of Victorine affectivity, ${ }^{18}$ the brilliance of Barbezat's contribution is to dissect how within Hugh's theology the significance of Augustinian affectus was grafted onto the characteristic ideals of the life of Victorine canons regular: ideas such as man as imago Dei, the necessary unification of knowledge and love, the stages of emotional regulation and spiritual contemplation as well as the programme of man's restoration through reform, ethics and preaching.

The seventh offering, «Affectus in the De spiritu et anima and Cistercian Writings of the Twelfth Century» (pp. 86-96) by Constant J. Mews, furthers our knowledge of texts 'On the Soul', a genre specifically favoured by high profile mystics of the Cistercian Order such as William of Saint-Thierry, Aelred of Rievaulx and Isaac of Stella. Mews here distils the

\footnotetext{
${ }^{16}$ Ruys, J., The Repentant Abelard: Family, Gender, and Ethics in Peter Abelard's Carmen ad Astralabium and Planctus, New York, Palgrave Macmillan, 2014.

${ }^{17}$ Rorem, P., Hugh of St. Victor, Oxford, Oxford University Press, 2009, pp. 129-154; Rudolph, C., The Mystic Ark: Hugh of Saint Victor, Art, and Thought in the Twelfth Century, Cambridge, Cambridge University Press, 2014.

${ }^{18}$ Ganss, K., «Affectivity and Knowledge Lead to Devotion to God: A Historical-Theological Study of Hugh of Saint Victor's De virtute orandi'», in H. Feiss and J. Mousseau (eds.), A Companion to the Abbey of Saint Victor in Paris, Leiden, Brill, 2017.
} 
findings of his recent analyses ${ }^{19}$ of the overwhelmingly popular treatise, De spiritu et anima ('On the Spirit and the Soul'), which he argues should be attributed to the physicus, Alcher of Clairvaux (pp. 87 and 90). This study is invaluable reading for anyone seeking to greater understand the sources (Platonic, Augustinian, and Boethian) of Cistercian faculty psychology, and how the treatment of the affections across Cistercian psychology was expressly concerned with trying to minimise the issue of body-soul dualism, inherent in Augustine's psychology.

The eighth contribution originating from the pen of Barbara Newman is entitled «Affectus from Hildegard to Helfta» (pp. 97-107). Comparing the use of the term affectus within the Hildegardian corpus and the Liber specialis gratiae ('The Book of Special Grace'), written communally at Helfta c.1291-1299, Newman is perceptive of the gendered nature of this term. While affectus is 'not a keyword for Hildegard' (p. 100) and is virtually absent from her writings - likely due to the magistra's literary self-fashioning as a prophet (p. 99) - the embrace of the term affectus by the (Rosenwein-esqe) affective community at the elite Saxon nunnery of Helfta - to designate the warm mutual friendship that yoked the sisters together with one another and God - reveals that a term, associated with schoolmen, could, by the turn of the fourteenth century, be adopted by monastic communities of women as their own. Such an account is overall persuasive, however, I was surprised by Newman's assertion that 'Hildegard has no explicit theory of the emotions' (p. 100) and that instead of 'feelings' or 'neutral dispositions of the soul', for Hildegard, emotions words such as amor ('love') and ira ('anger') 'represent virtues and vices' (p. 101). It is certainly true that Hildegard is never concerned with explicitly spelling out a theory of emotion, yet, as the essays from Mews and others in this volume show, affectivity was intimately connected with theological understandings of the virtues and vices, practices and habitus. Consequently, here it would have been useful to see more space given to the intersection between feelings and virtue, coming under the more general heading of affectivity within Hildegard's thought - although it is understandable that in a volume so tightly focused on affectio and affectus that the required space could not be found.

The final essay in this quintet of studies devoted to medieval religious orders is that of Tomas Zahora on "Affect, Affections, and Spiritual Capital in the Thirteenth Century» (pp. 108-120). Drawing upon research that has sought to recognise affect as a learned practice $^{20}$, most overtly the concept of 'spiritual capital' devised by Monique Scheer ${ }^{21}$ (who, in turn, modified Bourdieu's notion of habitus), Zahora's treatment of Franciscans

\footnotetext{
${ }^{19}$ Mews, C.J., «The Diffusion of the De spiritu et anima and Cistercian Reflection on the Soul», Vitator, 49/3 (2018), pp. 297-330; «Debating the Authority of Pseudo-Augustine's De spiritu et anima», Prezglad Tomistyczny, 24 (2018), pp. 321-348.

${ }^{20}$ See McNamer, Affective Meditation, (2010) [note 9 above]; Bale, A., Feeling Prosecuted:Christians, Jews and Images of Violence in the Middle Ages, London, Reaktion Books, 2010); Somerset, F., Feeling Like Saints: Lollard Writings after Wyclif, Ithaca, N.Y., Cornell University Press, 2014; Crocker, «Medieval Affect Now», op. cit.

${ }^{21}$ Scheer, M., «Are Emotions a Kind of Practice (and Is That What Makes Them Have a History)? A Bourdieuian Approach to Understanding Emotion», History of Theory, 51/2 (2012), pp. 193-220.
} 
Bonaventure and David of Augsburg deftly highlights that while affectio served as a synonym for passio ('passion'), affectus often denoted the active, educable dispositions of the will. This finding, when twinned with Neslihan Şenocak's ${ }^{22}$ discovery that the Franciscans justified their elite position and status as a class of brothers who possessed high educational and intellectual achievement through a discourse that attributed value to intellectualistic activity, reveals the understudied connection between affectus, habituation and the emotional training undergone by the spiritual elite. Insights such as these are vital as they pave the way for new avenues of research to be conducted: for instance, studies that trace the relationship between the proficiency of affective practices and age.

From this point on, the articles of Before Emotion transition from grappling with the Augustinian legacy of the affections to that of the tradition ushered in by Thomas Aquinas. Robert C. Milner's piece, «Affectus and passio in the Summa theologiae of Thomas Aquinas» (pp. 121-130), offers a careful reading of the terms affectus and passio and their connection to the Thomistic theory of bodily identity. For Thomas, affectūs are produced by the intellectual capacity of the will in rational creatures (man, angels and God). Yet, alongside the affectiones - unlike God and the angels - man's psychology is also predicated on the passiones experienced passively by the sensible soul, leaving open the problematic possibility of a dualistic soul-body divide. Milner's 'radical interpretation' of affectivity in Thomas's Summa, however, suggests that instead of two movements, the affections and the passions were rather thought of as by Aquinas as «a single motion... both 'sensibly intellectual' and 'intellectually sensible'». (p. 128). This innovative interpretation explains not only why Thomas did not dedicate a section of his Summa to the intellectual affectūs (129) but also offers a coherent model of the affections that concurs with existing understandings of Thomistic metaphysics, especially that of hylomorphism. Milner's essay shows, therefore, how a focus on affectus can lead to new readings of extensively studied texts. Affectivity as conceived here allows a greater focus on the interaction - rather than the division - between the affections and passions in Aquinas, further indicating the blurred boundaries of soul and body in medieval scholastic thought.

Next, Naama Cohen-Hanegbi's «Accidentia anime in Late Medieval Medicine» (pp. 131141) helpfully highlights how within the genre of medicine, despite passiones being the sixth category of non-naturals, it was the term accidentia anime that rose to prominence, not affectus. Much like Hildegard, the physicians of the later Middle Ages consciously distanced themselves from the term in favour of 'accidents of the soul', which was more malleable, and importantly, possessed a greater neutrality: the translation of the Arabic 'Awāri (lit. 'incidents') coming without the ethical and theological baggage of affectus (pp. 132-133).

The twelfth essay, «Affeccioun in Middle English Devotional Writing» (pp. 142-155) by Paul Megna, proposes to nuance understandings of the vernacular affeccioun within key

${ }^{22}$ Şenocak, N., The Poor and the Perfect: The Rise of Learning in the Franciscan Order, 1209-1310, Ithaca, New York, Cornell University Press, 2012. 
texts such as the Ancrene Wisse, The Cloud of Unknowing and The Book of Margery Kempe. Overall, Megna argues that the widespread use of affeccioun to refer to holy and sinful forms of desire may lead us to supplement widely used, general concepts such as 'affectionate piety' with more specific, contextually descriptive, labels such as 'compassionate piety' and 'dreadful piety' in order 'to develop a more nuanced understanding of late medieval Christianity's myriad, always overlapping and interacting forms of emotional devotion' (p. 149).

«The Renaissance of affectus? Biblical Humanism and Latin Style» (pp. 156-169) moves Before Emotion further along in time to examine the reception of affectus in the Renaissance tradition. Behind editor Kirk Essary's questioning title is a close study of how dictionaries serve as important witnesses in the discursive history of affectivity. Erasmus rejected the idea that affectio referred to the lower (crassior) movements of the body, whereas affectus signalled the 'higher' affective dispositions of the soul, preferring to speak of both pious and problematic affectus. Here, I found Essary's point that Erasmus was motivated to adopt a duplex affectus from Quintilian in part due to defend his usage of affectus in his Novum Testamentum (1516) from attacks by the Flemish Franciscan Francis Tittelmans particularly significant for what is says about the role of rhetorical conflict in shaping Latin emotional terminology.

Continuing the use of dictionaries is Elena Carrera's contribution, «Augustinian, Aristotelian and Humanist Shaping of Medieval and Early Modern Emotion: Affectus, affectio, and 'affection' as Travelling Concepts» (pp. 170-184). Carrera shows that among monolingual dictionaries - such as the 1499 issue of the Catholicon, the 1502 dictionary of Ambrose Calepine, The Dictionary of Sir Elyot (1538), and Juan Luis Vives' De officio mariti (On the Office of the Husband) - there was a reluctance to parse affectus as an 'emotional capacity' in favour of a much wider variety of meanings (p. 177). Importantly, Carrera helpfully highlights that more awareness for the role of historical context in unpicking translations of affectus is necessary. Without an appreciation of context, it would be impossible to understand the social class dimension at play in Vives's rendering of affectūs as both controllable and uncontrollable emotions, as he was writing for husbands and thus was more concerned about 'ordinary people's experiences of affectus in a wider range of situations' (176). Insights such as these will enable the diverse matrices of social class - also treated by Zahora in the Franciscans - and its relationship to affectus to be compared in future studies.

Following a series of essays that microscopically examine individual case studies of affectus, the essay of R. S. White-«Meta-, Mega-, and Multiple Emotions in Early Modern Terminology» (pp. 185-199) - takes a refreshing step out of the frame to ask 'big picture' questions regarding the etic concepts used by early modern historians to categorise emotion. For White, meta-terms describe internal and mental processes (i.e. 'passions' and 'affections'); mega-terms reflect feeling-states (i.e. irascibility, concupiscibility, the humours); whereas multiple emotions encompass the hundred or more singular emotions 
such as joy, shame and fear that White has identified. A framework such as this, if adopted in scholarship, may assist the precision of future studies.

The sixteenth article is that of Anik Waldow, entitled «Reconceptualizing Affect: Descartes on the Passions» (pp. 199-211). Exploring Descartes' treatise on the passions, Les passions de l'âme (The Passions of the Soul), Waldow highlights how, like other authors in this volume, Descartes avoided the technical term affectus in preference for 'passion' on account of the former's connection to Aristotelian scholastic philosophy. Descartes was 'trying to distance himself from a metaphysical set-up that, to his mind, imbues matter with powers it does not have' (p. 208). This choice, as Waldrow clearly explains, was in keeping with Cartesian metaphysics which sought to do away with the scholastic distinction between the irascible and concupiscible passions, located under the remit of the sensitive soul, and instead argue that the passions fell under the domain of the intellect.

Engagement with Cartesian tradition features also in the next essay, «Defining the Emotions in the Post-Cartesian Humanism of Giambattista Vico» (pp. 212-228) by Daniel Canaris and Francesco Borghesi. The duo persuasively shows how Vico's early poem of 1693, Affettii di un disperato (The Affects of a Man in Despair), was produced in reaction to his discovery of the dominance of Cartesian thought at Naples. Thus, while drawing on Descartes, Vico contests many of his ideas and paints the affections in a bad light (p. 215) - a stance that would persist with his Second Inaugural Oration (1700) in which the affectūs are considered as characterising the 'foolish' (stultus) (p. 218). However, in his more mature works, such as the Diritto Universale (Universal Law) and Scienza nuova (New Science), Vico was much more concerned about the political effects of the affetti and passioni and less about their physiological origin, considering them as the natural consequences of postlapsarian man (pp. 220-222). Vico's U-turns on the subject thus show the organic developments in approaches to the affections, and how coming to terms with fluctuating, contradictory viewpoints is necessary for historians.

Margaret Watson's «Unprincipled by Principle: On Hume's Use of 'Affection'» (pp. 229-239) marks the penultimate contribution of the volume. Much like Canaris and Borghesi did for Vico, Watson seeks to understand David Hume's 'messy use of affection' (p. 229). In Hume there is a key theme that we have already encountered: the active, educable nature of the affections, what is termed by Hume as 'sentiment'. However, characteristic of his experimental approach to philosophy, Hume resists 'the long-standing practice of vilifying the passions' (p. 236) and, at the dawn of the modern era, displayed a preference for dissolving ancient distinctions.

The concluding essay of Before Emotion is Michael W. Champion's «From affectus to Affect Theory and Back Again» (pp. 240-255). As the grand finale of the volume, Champion's purpose is twofold: firstly, to summarise the themes at the heart of this volume; and secondly, to use these themes as evidence of the flaws of modern affect theory.

Regarding the first purpose of his essay, Champion is right in his assertion that this volume's study of affectus over the longue durée offers support for understanding affect as 
embodied practices at the heart of individual, communal, and social formation' (p. 245). Summarising many of findings of the papers of this collection, he sets out four overlapping areas of significance that studies of the affections can offer:

1. Affectus and habitus: most essays suppose a link between affectus and performances, intentionality, or habitus as an ethical and spiritual practice (pp. 245-6). Drawing on Scheer's notion of 'spiritual capital', interpretations of affectus as a disposition of the will, for example, often accept the input of the faculty of reason or intellect in the habitualization and education of the soul over time to adapt its affective responses or to proceed to more advanced emotional states.

2. Affective relationships: «...one of the clearest unifying themes across our period», Champion notes, «....is the capacity of affectus to create relationships and motivate actions across multiple domains, including political action» (p. 247). Each study here has consistently highlighted the role of emotions in binding (and unbinding) people together. The significance of affectus in the shaping of so-called 'affective communities' - explicitly examined in the contributions of Barbezat, Newman, Zahora, Megna and Carrera - serves to push understandings of the social function of affectivity forward whilst justifying the use of core methodologies in the history of emotions (i.e. Rosenwein's' emotional community).

3. Morality: articles in this volume stress the connection between the affections and ethical behaviour. For Augustine the affectiones were neutral (Teubner); for Thomas Aquinas the affections were the positive movements of the rational soul, the passions the undesirable motions of the irrational soul (Milner); for Erasmus affectus encompassed both the problematic and pious states of feeling (Essary); for Vico affections were a natural attribute of postlapsarian existence (Canaris and Borghesi); whereas Hume tried to do away with the dichotomy altogether (Watkins). «In societies that value emotional practices of moderation, reserve, and constraint, one might expect affectus to be coded positively when linked to a detachment which plays down the physicality of emotion», Champion states (p. 247). Such a theme is found across the Platonic, Stoic and Aristotelian emotional traditions; traditions that, as this volume shows, commanded great influence across the medieval and early-modern worlds.

4. Bodily identity: the distinctions between mind and body permeate understandings of affectus. As Champion suggests, philosopher Charles Taylor's notion of the "porous self ${ }^{23}$, the permeability of the body to outside forces and entities, helps explain several of the theories of affectivity in this volume in which affectus joins humans to places, animals, communities, angels, and ultimately God' (p. 248).

${ }^{23}$ Taylor, C., A Secular Age, Cambridge, Massachusetts, Harvard University Press, 2007. 
To these four I would like to suggest three further overarching categories Before Emotion exposes:

1. Duration: a key theme in defining an affectus and an affectio is often their short duration. The Ciceronian tradition, sa covered by Copeland, appears to have emphasised this trend: affectio being defined by Cicero as a 'temporary disturbance (ex tempore... commutatio), for some reason, of mind or body' (Copeland, 39). Augustine, too, distinguishes between the temporal affections of man and the heavenly constantiae (Teubner, 18); the sixteenth century term 'affections of the mynde' denoted transient states of mind (Carrera, p. 174); the Renaissance figures Essary studies borrow from Cicero in viewing 'anger as an affectus, irascibility as an ingrained norm' (p. 159); and finally White, speaking on dictionary sources, states that «...passions lie at the realm of constants... while affections (like 'motions') are variable and subject to circumstantial change...» (p. 188). This sensitivity to the relationship between time and affectivity may offer a complement to the ideas of affectus as a habitus.

2. Agency versus passivity: Champion et al. have suggested elsewhere that affectus is 'primarily passive' indicating 'some mental, volitional, or psychic movement caused by external action' ${ }^{24}$ Waldow's study of Descartes confirms such a view (208). Yet the accounts of Aquinas' theology (Milner), the use of accidentia anime by physicians to diagnose illness (Cohen-Hanegbi), dictionaries (Cohen and White), Vico's political theory (Canaris and Borghesi) and Hume's philosophy (Watkins), all emphasise the role of affectus as an action (actio), thus bringing into question such totalising assumptions. Indeed, as Carrera suggests, all the key writers of the affective tradition - stretching back to Ambrose and Augustine in addition to encompassing major religious orders in this volume - the Victorines (Barbezat), the Cistercians (Mews), the Benedictines (Newman) and the Franciscans (Zahora) - each 'used the noun affectus to refer to a state of mind which was best understood not as a passive surrendering to God's action on the soul, but as an active engagement with it' (p. 172).

3. Reception: As a concept, affectus attracted users to it, yet simultaneously due to its conceptual baggage, repelled others of a certain gender, social class, age or inclination, away from it. Augustine was attracted by its neutrality (Teubner), yet Hildegard (Newman), physicians (Cohen-Hanegbi) and Descartes consciously sought to distance themselves from it. These findings, as well those of Mews, which show so clearly the acceptance and rejection of classical and late-Antique philosophy relating to the emotions within a Cistercian milieu, or Essary's discovery that Erasmus deliberately conflated affectio and affectus to 'score rhetorical points' against his critics, emphasise the importance of closer attention to

${ }^{24}$ Champion et al., «But Were They Talking About the Affections?», op. cit., pp. 524. 
whole constellations of terms relating to affectivity in future studies of reception.

Champion's second purpose in his essay is to overhaul modern affect theory. He joins others ${ }^{25}$ in contending that affect theorists are misplaced for reducing all experience to mere bodily encounters. Lambasting such a view, he pithily remarks that according to affect theorist Eric Shouse, «We are sad because we cry, not sad because we learn that a child has died» (p. 242). Just shy of 250 pages of case studies to the contrary, such an idea, Before Emotion shows such a view to be risible and clearly an oversimplification of more complex phenomena. A dangerous consequence of affect theory, Champion warns, is that due to its disillusionment with the linguistic turn, affect theorists respond «by seeking to re-insert the non-discursive into the picture» yet always fall back on discursive strategies such as ambiguous metaphors, since «affect cannot be reduced to language» (p. 244). Overall, similar to theoretical physics, affect theory blurs the distinction between the human and the rest of the world in an attempt to establish a unified explanation of cause and effect (p.242) - an approach so palpably at odds with the history of premodern theories of emotion surveyed in Before Emotion.

Is it possible to achieve a synthesis between affect theory and linguistic studies of emotion? For Holly Crocker, there is hope for an optimistic future: «modern affect theory should not be jettisoned, but it should be revised to account for the ways that spiritual life might re-orient embodied identities.» ${ }^{26} \mathrm{~A}$ reader of Champion's treatment of the question here may find that optimism tempered by a (healthy?) dose of scepticism. Reading his impassioned account for the potential synergies that a balanced focus on both the 'body' and 'discourse' offers, exemplified through the methodologies of Scheer and Crocker, I get the impression from statements that the application of affect theory as it stands to the premodern is 'ultimately futile' or that 'much contemporary affect theory sublimates medieval thought in a fetishization of the modern', seem to suggest that the differences between these two methodologies may be too difficult to overcome. In my opinion, greater collaboration, and the potentiality for fruitful dialogue between disciplines - especially two which are currently polarised - is always useful. However, time will tell whether the sceptical approach of Champion, or the optimism of Crocker, will be validated.

No work is perfect, even that of the calibre of Before Emotion. The index is concise, but welcome. One could quibble over minor typographical errors (for instance, Richard of Saint-Victor died in 1173 not 1137 as stated by Carrera on page 172). Likewise, I felt it was a misstep that the editors did not include a glossary, however brief, of key terms; at numerous stages throughout the book, I wished that a tabulated list of all the possible meanings affectus and affectio had been provided to aid readers in making synoptic comparisons

${ }^{25}$ For a summary see Leys, R., «The Turn to Affect: A Critique», Critical Enquiry, 37/3 (2011), pp. 434472.

${ }^{26}$ Crocker, «Medieval Affects Now», op. cit., p. 91. 
of these terms. Yet the most telling indicator of the success or failure of this volume is its methodology: the utility of the discursive concept of affectus and its cognates as a comparative device. At points, the dizzying variety of translations, interpretations and uses of this term made me question the ability of the term to remain undiluted and sustain its explanatory power. Repeatedly the articles of this volume, however, have assuaged this fear and shown just how embedded affectivity was into discourses of learned behaviours, affective communities and bodily identities, reinforcing the need for further investigation into this key word.

Who, then, is the target audience of Before Emotion? Distilling the latest research by senior academics on the affections, this new volume has been written for scholars working within this, or a closely related, field. Those working more generally on the history of emotions will also benefit from the contributions here to specific emotions or methodology. And to a lesser degree, scholars working on specific authors this book covers also stand to gain. Despite all the essays in the volume being written in a clear style, they do, admittedly, presuppose a high degree of previous knowledge, limiting its accessibility to students or those without an awareness of the authors, texts, and contexts that are treated here. Further, the relatively expensive price tag will unfortunately make nonspecialist libraries think take heed before purchasing this volume, potentially limiting the circulation of this masterful collection to a specialist audience. Routledge does offer the option of a cheaper eBook version, however, which may be a preferrable medium for many at a time of limited physical access to books due to the ongoing Covid-19 pandemic.

Nevertheless, Before Emotion remains a timely and thoughtful meditation on the significance of affectus, in addition to an intervention into affect theory. Historians have asked for a systematic overview of affectus in the history of premodern emotion and the collective efforts of Champion, Essary and Ruys have made it a reality. 